\title{
The Effect of Nutrition Education Towards Knowledge of Mothers with Children Under-five Years in Lempeni Village, Indonesia
}

\author{
Miftahul Jannah ${ }^{1, *}$, Sabran Sabran ${ }^{2}$, Putri Rahayu Ratri ${ }^{3}$ \\ ${ }^{1,2,3}$ Health Department, Politeknik Negeri Jember, Indonesia \\ "Corresponding author. Email: miftahuljannah@polije.ac.id
}

\begin{abstract}
Stunting is a major health problem that has been identified as one of the risk factors for poor physical and mental development among children under-five years. Lempeni is one of the villages in East Java, Indonesia with a stunting prevalence of $35 \%$. One of the ways to overcome stunting is by conducting nutrition education. Considering the importance of nutrition education, this study aimed to evaluate the effect of nutrition education on the nutritional knowledge of mothers with children under-five years in Lempeni Village, Indonesia. This was a quasi-experiment with no control group. The study was undertaken among 8 mothers selected purposively. Nutrition education was carried out by giving a lecture using power points and combined with a demonstration on how to detect stunting and make complementary foods. Nutrition knowledge scores before and after the intervention were analyzed using Wilcoxon Signed Rank Test. The mean of the mothers' knowledge score before intervention (pretest) was $18.5 \pm 1.512$ while the mothers' knowledge score after intervention (posttest) was $19.63 \pm 1.506$. The nutrition knowledge scores were significantly higher in the posttest than the pretest after receiving nutrition education $(\mathrm{p}<0.05)$. According to the results, nutrition education had a positive impact on the nutrition knowledge of mothers with children under five years old. It can be concluded that nutrition education was effective in increasing the mothers' knowledge
\end{abstract}

Keywords: Children under-five years, Knowledge, Nutrition education, Stunting

\section{INTRODUCTION}

Stunting is a condition of nutritional adequacy in toddlers which is currently a major concern of the government. This is because stunting can have an impact on the intelligence of toddlers who are the nation's assets in the future. One of the factors that affect a person's nutrition is the lack of nutrition knowledge. Nutrition education can be done through counselling on targets. The importance of nutrition education for stunting prevention needs to be considered [1]

Nutrition education aims to change behaviour that pays less attention to nutrition in intake to pay more attention to nutrition [2]. In addition to education problems, poverty is also a factor in the emergence of nutritional problems, supported also by low knowledge of nutrition. In the case of stunting, of course, the emphasis is on the attitude and knowledge of nutrition in mothers in giving the right food. Good nutrition knowledge will encourage mothers to practice good feeding for children [3].

A higher level of education about nutrition will certainly make someone receive information in terms of nutrition easily. The knowledge possessed will begin with a stimulus to do what is known in the aspect of the practice of providing nutritious food to children [4]. The importance of nutrition education certainly pays attention to the impact it has, especially during a pandemic like today. Inappropriate consumption patterns will have an impact on malnutrition which will increase the risk of various diseases [5]

Therefore, nutrition education and stunting are closely related. In detecting stunting, of course, it cannot be separated from the role played by the Posyandu as the closest toddler health facility. The phenomenon that occurs during the current pandemic is the reduced intensity of mothers being able to go to the Puskesmas or Posyandu and get nutrition education for their families, especially children. If this is left unchecked, it 
can have an impact on stunting rates in children. In addition, limited access to information is one of the factors that must be addressed immediately. This condition occurs in almost all regions in Indonesia.

Partners in community service are Posyandu officers and mothers of toddlers in Lempeni Village located in Tempeh District, Lumajang Regency, East Java where the Covid-19 pandemic caused limited Posyandu services so that the community and cadres were limited to Posyandu to get services and further knowledge related to stunting. Based on the results of the situation analysis of 32 households, there were several problems faced by the community, including: (1) the stunting rate in children under five years old in Lempeni Village, (2) the lack of application of balanced nutrition in Lempeni Village, (3) the coverage of exclusive breastfeeding had not been achieved based on the Ministry of Health's Minimum Service Standards target, and (4) the activities at the Posyandu were not optimal due to the Covid-19 pandemic. Therefore, based on the description above, the researchers intended to increase the nutritional knowledge of Posyandu officers and mothers of children under five years old through online and offline counselling to increase knowledge and prevent stunting in Lempeni Village.

\section{METHOD}

This experimental study was conducted to examine the effect of nutrition education on the knowledge of mothers with under-five years old children in Lempeni Village, Lumajang, East Java. Eight mothers who participated in this study were recruited using purposive sampling. The data gathering instrument was a 2-part questionnaire. The first part was used to obtain demographic characteristics of the participants, and the second part was used to gather knowledge scores of the participants. The data were analyzed using SPSS for Windows version 20. Wilcoxon rank test was used to compare the knowledge score of the mothers before and after the intervention.

\section{RESULTS AND DISCUSSION}

Based on the results of statistical tests, it was known that there were significant differences both in the knowledge of mothers of children under five years old and knowledge of cadres before and after activities. This could be seen from the knowledge scores that increased after being given counselling in Table 1. For the mothers of toddlers, the knowledge score before being given counselling was 18.5 , while the score after being given counselling was 19.63. For cadres, the knowledge score before being given counselling was 8.4 , while the score after being given counselling was 9.8 .
Table 1. Increased knowledge of mothers of toddlers and cadres

\begin{tabular}{lccc}
\hline $\begin{array}{c}\text { Knowledge } \\
\text { Scores }\end{array}$ & $\begin{array}{c}\text { Before } \\
\text { intervention }\end{array}$ & $\begin{array}{c}\text { After } \\
\text { intervention }\end{array}$ & p value \\
\hline $\begin{array}{l}\text { Mothers' } \\
\text { knowledge } \\
\text { scores }\end{array}$ & 18.5 & 19.63 & 0.014 \\
\hline $\begin{array}{l}\text { Cadre } \\
\text { knowledge } \\
\text { scores }\end{array}$ & 8.4 & 9.8 & 0.038 \\
${ }^{*}$ ) & & & \\
\hline
\end{tabular}

${ }^{*)}$ Wilcoxon Rank Test

Apart from these data, indicators of increasing knowledge were also seen during the question and answer process between resource persons and participants (cadres and mothers of toddlers). During the process, there were some wrong perceptions or knowledge that the participants had, then the resource person gave the correct response/answer to the participants so that participants understood. At the end of the activity, games related to counselling and training materials were also carried out with the results that participants were able to answer correctly.

An increase in knowledge among mothers of toddlers and cadres could show that the activities carried out were successful. The results of this study were in line with the research of [6] that there was a significant difference between mothers' knowledge before and after being given nutritional counselling about MP-ASI ( $\mathrm{p}=$ $0.000)$. Changes in the mother's knowledge increased better after being given nutrition counselling. In addition, the results of this study were also in line with a study that showed that there was a significant increase in the knowledge of health cadres after intervention $(\mathrm{p}=$ $0.000)$ through nutrition counselling activities with the lecture method and training of health cadres in early detection of stunting and stimulation of children's growth and development [7]

Nutrition education is a very important part of an effort to improve community nutrition. Counselling and education provided can affect a person's level of knowledge and behaviour in acting so that behavioural patterns are formed that change for the better [8]. Mothers of toddlers and Posyandu cadres have a very important role in improving the nutritional status of toddlers. The better the mothers' knowledge, the better the quantity and quality of food given to toddlers, so that the nutritional intake of toddlers is also fulfilled properly [9]. In addition, the better the knowledge of the cadres, the greater the success of Posyandu activities.

The existence of games in knowledge-building activities helped facilitate the delivery of material to participants to make it understood easily. Games can generate motivation, train skills, and increase perception and stimulation so that the ability to understand and solve problems [10]. 


\section{CONCLUSION}

The provision of training through counselling to mothers and Posyandu cadres is very influential in increasing nutritional knowledge.

\section{AUTHORS' CONTRIBUTIONS}

All the authors contributed to proposal writing, data collection, data analysis, and article writing.

\section{ACKNOWLEDGMENTS}

This study was funded by the Ministry of Education, Culture, Research, and Technology of the Republic of Indonesia

\section{REFERENCES}

[1] Nuryanto, Pramono A, Puruhita N, Muis SF. Pengaruh pendidikan gizi terhadap pengetahuan dan sikap tentang gizi anak Sekolah Dasar (The influence of nutrition education on knowledge and attitudes about nutrition of elementary school children). J Gizi Indones [Internet]. 2014;3(1):326. Available from: http://journal.binawan.ac.id/index.php/bsj/article/vi ew/52/53\%0Ahttp://ejournal.poltekkes-

smg.ac.id/ojs/index.php/jrg/article/view/4311/1163

[2] Ariyana R, Mintarsih SN, Jaelani M, Subandriani DN. Pengaruh Edukasi Gizi terhadap Pengetahuan, Sikap dan Kepatuhan Diet Penyandang Diabetes Melitus Tipe II Peserta Prolanis di Puskesmas Pamotan Kabupaten Rembang (The Effect of Nutrition Education on Knowledge, Attitudes and Diet Compliance with Type II Diabetes Mellitus Participants in Prolanis at Pamotan Health Center, Rembang Regency). J Ris Gizi. 2018;6(2):25-30.

[3] Khomsan A, Anwar F, Mudjajanto ES. Pengetahuan, Sikap, Dan Praktek Gizi Ibu Peserta Posyandu. J Gizi dan Pangan. 2009;4(1):33.

[4] Amalia F, Nugraheni SA., Kartini A. Pengaruh Edukasi Gizi Terhadap Pengetahuan Dan Praktik Calon Ibu Dalam Pencegahan Kurang Energi Kronik Ibu Hamil (Studi pada Pengantin Baru Wanita di Wilayah Kerja Puskesmas Duren, Bandungan, Semarang) (The Effect of Nutrition Education on Knowledge and Practice of Prospective Mothers in Prevention of Chronic Energy Deficiency in Pregnant Women (Study on Newlyweds in the Work Area of Duren Health Center, Bandungan, Semarang). J Kesehat Masy. 2018;6(5):370-7.

[5] Permatasari TAE, Turrahmi H, Illavina. Edukasi Gizi Seimbang Bagi Kader Posyandu Pada Masa Pandemi Covid-19 Sebagai Pencegahan Balita
Stunting Di Kabupaten Bekasi (Balanced Nutrition Education for Posyandu Cadres During the Covid19 Pandemic To Prevent Stunting Toddlers In Bekasi Regency). J Antara Abdimas Keperawatan. 2021;4(1):1-10.

[6] Kustiani dan Misa. 2018. Perubahan Pengetahuan, Sikap, dan Perilaku Ibu dalam Pemberian MP-ASI Anak Usia 6-24 Bulan Pada Intervensi Penyuluhan Gizi di Lubuk Buaya Kota Padang (Changes in Knowledge, Attitudes, and Behavior of Mothers in Giving MP-ASI to Children aged 6-24 Months in Nutrition Counseling Interventions in Lubuk Buaya, Padang City). Jurnal Kesehata Perintis, I5 (1).

[7] Adistie, Maryam, dan Lumbantobing. 2017. Pengetahuan Kader Kesehatan Tentang Deteksi Dini Gizi Buruk pada Balita (Knowledge of Health Cadres About Early Detection of Malnutrition in Toddlers). Jurnal Aplikasi Ipteks, 6(3).

[8] Suhardjo, 2003. Berbagai Cara Pendidikan Gizi (Various Ways of Nutrition Education). Jakarta: Bumi Aksara

[9] Burhani, Oenzil, dan Revilla. 2016. Hubungan Tingkat Pengetahuan Ibu dan Tingkat Ekonomi Keluarga Nelayan dengan Status Gizi Balita di Kelurahan Air Tawar Barat Kota Padang (Relationship between Mother's Knowledge Level and Fisherman's Family Economic Level with Nutritional Status of Toddlers in Air Tawar Barat Village, Padang City). Jurnal Kesehatan Andalas, 5(3).

[10] De Aguilera, M., dan Mendiz, A. 2003. Video Games and Education: (Education in the Face Of A "Parallel School"). Computers in Entertainment, 1 (1), 1-10. 